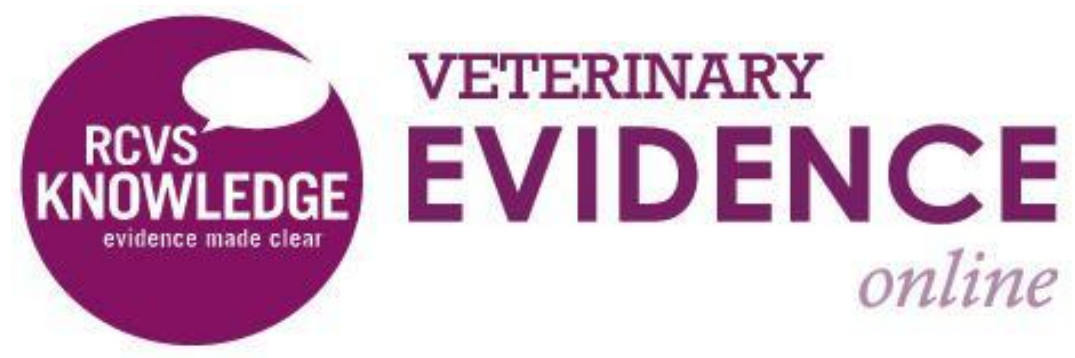

\title{
Brexit and Veterinary Research
}

A Commentary by

Professor the Lord Trees BVM\&S, PhD, DVetMed (hc), DVMS, MRCVS, Hon FRSE

ISSN: 2396-9776

Published: 30 Nov 2016

in: Vol 1, Issue 4

DOI: http://dx.doi.org/10.18849/ve.v1i4.72 
Currently there are only two things we can be certain of with regards to Brexit. One - it means Brexit! Two - in the long term, we just don't know how it will affect us.

I voted to Remain. I am a unionist. Not so much out of any analysis of the balance sheet - better off in or out? - but because life tells me that we are all stronger if we work together. As an individual, a family, a community, a nation we are better equipped to respond to and survive the slings and arrows of fortune together than alone. In a chemistry analogy, we have a greater 'buffering' capacity. But, in the cliché of the moment, we are where we are. So how might it impact on veterinary research in the UK?

There is not much doubt that in scientific research and collaboration generally, the UK has done very well as a member of the EU. During the last 15-20 years the emergence of research support from the EU has been an important new income stream for UK institutes and universities. Whilst the overall input of funds from the UK to the EU exceeds what we get back by about $£ 8-10$ billion per year ${ }^{1}$, analysis suggests that our contribution for research is substantially exceeded by what we receive back; over the period 2007-2013 the UK received $€ 8.8$ billion in direct EU funding for research, development and innovation activities while contributing only $€ 5.4$ billion $^{2}$. So UK scientists have been very successful in winning competitive grants from the EU. An important aspect of the EU funding has been that much of it has been focussed on applied research with practical outcomes. This has been particularly useful for veterinary research where, in many cases, we seek downstream research objectives such as tools for diagnosis, surveillance or control of diseases. These areas have historically not been so well supported by UK Research Councils (although that is changing). I personally have benefitted from several EU research grants for purposes which address immediate disease problems.

Another indirect form of EU support for research, which is of particular importance to animal health, is the EU support for UK institutions designated as EU Reference Laboratories. In 2011 the European Commission allocated nearly $€ 1.5$ million to UK based reference laboratories in the field of animal health and live animals including the Veterinary Laboratories Agency (now AHVLA) and the Institute for Animal Health (now The Pirbright Institute).

Apart from the actual support for research, EU grants have usually involved - indeed required -multinational collaboration, and this has been a hugely valuable aspect fostering and enabling fruitful collaborative networks both within Europe and between Europe and developing countries, especially in Africa. Other smaller but nonetheless valuable EU schemes to encourage research networks (e.g. the COST framework (European Cooperation for Science and Technology) $)^{3}$ ) have brought together scientists working on problems such as coccidiosis, neosporosis, toxoplasmosis, helminth infections and anthelmintic resistance, to name but a few within my area of speciality, which have yielded benefits far exceeding the relatively modest costs. All these sources of funding are not going to be automatically available post-Brexit, but we shouldn't assume they will not be open to our participation. There are mechanisms - and examples already exist - where non-EU members can be part of EU funded projects, although not as leaders ${ }^{4}$. Scientists are generally collaborative creatures and I am confident we will be able to negotiate, to mutual advantage, participation in EU research projects in the future. It needs to be said too that many large European research projects - although I think none of direct veterinary relevance - such as CERN (the European Organization for Nuclear Research), are collaborations between European countries independent of the EU per se, and they will not be affected by Brexit. Furthermore we need to recognise that our research collaborations extend far beyond the EU - notably with North America, but also Africa and many Commonwealth countries. The recent Nobel awards emphasised this by recognising the achievements of several British scientists who currently work in the USA.

An important impact on veterinary research in the UK relates to the mobility of researchers and post-graduate students from other EU member states. Nearly a quarter of academic staff in our veterinary schools (some 22\%) are EU nationals ${ }^{5}$. These staff make a critical contribution to teaching and research in both clinical and non-clinical areas. This situation is not, of course, unique to veterinary science. It is unequivocally not in our 
national interest to inhibit that vital contribution from EU nationals, and it would be foolish and self-defeating to constrain it.

So in summary, I am optimistic that the implications of Brexit on research can be mitigated. There will be huge pressure on government from the higher education sector, research-based industry, business and commerce, and bodies like the Royal Society, Research Councils UK (RCUK) and the Wellcome Trust to maintain research support and collaboration and the mobility of research personnel. Economic growth depends to a large extent on innovation and technical progress; and governments depend for their survival on delivering economic growth. That enlightened self-interest is our greatest guarantee that the government will try to ensure that Brexit will not seriously damage the UK's deserved reputation for research excellence. Of course, many other sectors will be arguing for special consideration in the Brexit negotiations, and for favoured treatment from the UK Treasury post-Brexit. We will need to make our case strongly and persistently. Rest assured that I will do what I can in Parliament to reinforce this message.

\section{REFERENCES}

1. HM Treasury: European Union Finances (2015) European Union Finances 2015: statement on the 2015 EU Budget and measures to counter fraud and financial mismanagement [HM Treasury: European Union Finances] [online]. Available form: https://www.gov.uk/government/uploads/system/uploads/attachment data/file/483344/EU fi nances 2015 final web 09122015.pdf [Accesses 17 Oct 2016]

2. The Royal Society (2015) UK research and the European Union The role of the EU in funding UK research. [The Royal Society] [Online]. Available from: https://royalsociety.org/ /media/policy/projects/eu-uk-funding/uk-membership-ofeu.pdf [Accesses 17 Oct 2016]

3. COST [COST European Corporation in Science and Technology] [online]. Available from: http://www.cost.eu/ [Accesses 17 Oct 2016]

4. House of Lords Science and Technology Select Committee report: EU membership and UK science, April 2016 [House of Lords] [online]. Available from: http://www.publications.parliament.uk/pa/ld201516/ldselect/ldsctech/127/127.pdf [Accesses 17 Oct 2016]

5. Brexit - Veterinary Fact File [Veterinary Policy Research Foundation] [online]. Available from: https://vprf.files.wordpress.com/2016/10/brexit-impacts-for-website.pdf [Accessed 17 Oct 2016] 


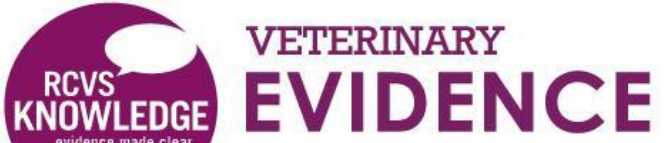 \\ orthe}

\section{Intellectual Property Rights}

Authors of Commentaries submitted to RCVS Knowledge for publication will retain copyright in their work, but will be required to grant to RCVS Knowledge an exclusive license of the rights of copyright in the materials including but not limited to the right to publish, re-publish, transmit, sell, distribute and otherwise use the materials in all languages and all media throughout the world, and to license or permit others to do

so.

Authors will be required to complete a license for publication form, and will in return retain certain rights as detailed on the form.

Veterinary Evidence and EBVM Network are RCVS Knowledge initiatives. For more information please contact us at editor@veterinaryevidence.org.

RCVS Knowledge is the independent charity associated with the Royal College of Veterinary Surgeons (RCVS). Our ambition is to become a global intermediary for evidence based veterinary knowledge by providing access to information that is of immediate value to practicing veterinary professionals and directly contributes to evidence based clinical decision-making.

\section{www.veterinaryevidence.org}

RCVS Knowledge is a registered Charity No. 230886. Registered as a Company limited by guarantee in England and Wales No. 598443.

Registered Office:

Belgravia House

62-64 Horseferry Road

London SW1P 2AF 